\title{
Post-Dural Headache with Seven Months Duration: Case Report
}

\author{
Fabiano Timbó Barbosa, TSA 1
}

\begin{abstract}
Summary: Barbosa FT - Post-Dural Headache with Seven Months Duration: Case Report.
Background and objectives: Post-dural puncture headache is a possible and expected complication in a small percentage of cases after spinal anesthesia. The objective of the current report was to describe the therapeutic conduct in a case of post-dural puncture headache with seven months of evolution.
\end{abstract}

Case report: A 40-year-old healthy female who complained of headache for seven months, which began after spinal anesthesia. She reported that some analgesics and decubitus position provided partial pain relief. An epidural blood patch was performed, with complete resolution of pain. She was discharged without complaints.

Conclusions: This case demonstrated that the epidural blood patch was effective in the treatment of chronic post-dural puncture headache in a case with seven-month evolution.

Keywords: Post-Dural Puncture Headache; Anesthesia, Spinal; Blood Patch, Epidural.

\section{INTRODUCTION}

Post-dural puncture headache (PDPH) is a well known and expected complication after perforation of the dura mater, although it has a small incidence with the use of thin needles, and its pathophysiology is not completely understood ${ }^{1-4}$. The literature has presented several headache indices with different gauges of Whitacre and Quincke needles ${ }^{1-3}$. Among the therapeutic strategies, epidural blood patch (EBP) is the most effective ${ }^{4}$ and it has been recommended for treatment of persistent headache after dural puncture ${ }^{1-3,5}$. The objective of this report was to describe the therapeutic conduct in a case of post-dural puncture headache with seven months of evolution.

\section{CASE REPORT}

We report a case of a 40-year-old female patient who was admitted with chronic headache. After the physical examination, the absence of comorbidities and similar prior episodes were observed. She did not have signs of illicit drug use, and the possibility of withdrawal syndrome was ruled out. The headache was predominantly frontal, non-pulsatile, and worsened when the patient was standing. Signs of transitory or perma-

Received from Universidade Federal de Alagoas, AL, Brazil.

1. MSc in Health Sciences; Professor of Universidade Federal de Alagoas

Submitted on May 27, 2010.

Approved on December 13, 2010.

Correspondence to:

Dr. Fabiano Timbó Barbosa

Rua Comendador Palmeira, 113/202

Farol

57051150 - Maceió, AL, Brazil

E-mail: fabianotimbo@yahoo.com.br nent neurologic damage were not observed. She also denied the presence of nausea, tinnitus, hearing symptoms, neck or dorsal rigidity, or fatigue. Physical examination and head CT were normal.

When questioned about pain characteristics she reported taking analgesics with little relief, and that the headache had started after a hysterectomy under spinal anesthesia seven months before the present admission. Her medical record was reviewed and it was confirmed that she underwent spinal anesthesia to treat a uterine myoma seven months ago in the same hospital. Anesthesia was performed with the patient in the sitting position, and puncture was successful in the first attempt at the $L_{3}-L_{4}$ level with a 27G Whitacre needle. No complications were observed during that previous procedure, and $15 \mathrm{mg}$ of hyperbaric bupivacaine was the anesthetic used.

We suspected of post-dural puncture headache and a blood patch was performed. The epidural space was identified with the loss of resistance technique with a $1.3 \mathrm{~mm}$ caliber (18G) Tuohy needle. The patient's venous blood was collected from the antecubital vein under aseptic condition, and $15 \mathrm{~mL}$ were injected slowly in the $L_{3}-L_{4}$ space. The patient did not complain of localized or irradiated pressure during the procedure. She remained in decubitus for 2 hours, being discharged from hospital 24 hours later without headache. After three weeks, she was contacted by telephone and informed she was free of pain since.

\section{DISCUSSION}

The International Headache Society has defined PDPH as bilateral headache that develops up to seven days after lumbar puncture and disappears up to 14 days after dural puncture ${ }^{6}$. As a rule, the pain affects the occipital or frontal region, but 
it can affect any area ${ }^{7}$. A study analyzed 8,460 patients who underwent subarachnoid anesthesia and were followed-up for six months ${ }^{8}$. This study's authors reported that $72 \%$ of PDPH cases have showed pain resolution within seven days of evolution and $87 \%$ in six months of follow-up.

The mechanism responsible for the development of PDPH is not fully known; however, the literature mentions two plausible possibilities.

First, the reduction in CSF pressure that can cause traction of painful structures when the patient is in the sitting or orthostatic position ${ }^{4}$. Normal CSF pressure in the horizontal position varies from 5 to $15 \mathrm{cmH}_{2} \mathrm{O}$; however, after neuraxial puncture this pressure can be lower than $4 \mathrm{cmH}_{2} \mathrm{O}{ }^{9}$. One study of 20 patients with PDPH who underwent magnetic resonance imaging after lumbar puncture demonstrated the absence of traction of structures, which suggests that this might not be the adequate model to explain the origin of headache ${ }^{10}$.

Second, the loss of CSF can cause compensatory venodilation to intracranial hypotension, which can maintain or cause the headache 4 .

The clinical manifestations of PDPH include: frontal or occipital headache, which is worsened by the vertical position of the body and it is relieved by decubitus; nausea and vomiting; hearing and visual symptoms; and posterior cervical muscular rigidity ${ }^{11}$. One test consisting in making continuous abdominal pressure for at least 30 minutes with one hand and the other on the dorsum or lumbar region observing the intensity of pain before removal of the hands can be useful when there is doubt about the diagnosis and headache is present ${ }^{12}$. The characteristic pain of PDPH disappears or decreases at the moment of compression and returns after release of the abdomen ${ }^{12}$. Headaches due to other causes do not improve with this maneuver. Another test that can help the diagnosis consists in digitally compressing the carotid artery, noting worsening of headache, and compressing the internal jugular vein, which improves the symptoms ${ }^{13}$.

The incidence of PDPH decreases with age and use of smaller caliber needles ${ }^{13-15}$. Needle gauge is the most important predisposing factor for PDPH 1,4,14, which can be exemplified by the incidence of $15.6 \%$ after the use of the $0.9 \mathrm{~mm}(22 \mathrm{G})$ Quincke needle and $1.4 \%$ after the use of the $0.3 \mathrm{~mm}(29 \mathrm{G})$ needle ${ }^{1}$. The use of non-cutting needles, such as the pencil-tip needle, has been associated with a reduction in the incidence of PDPH when compared with the same caliber Quincke needle ${ }^{4,15}$. If the age differences are corrected, the incidence of PDPH between genders does not seem different $4,6,14$.

It is known that the proliferation of fibroblasts begins approximately after 48 hours, and it continues for seven days after perforation of the dura mater facilitating the formation of collagen, which forms a permanent seal closing the orifice ${ }^{4,16}$. If the healing process does not occur, the CSF fistula can be- come chronic, keeping the pain for a prolonged time ${ }^{4,16}$. This is the pathophysiologic mechanism defended by the majority of authors as being responsible for post-dural puncture headache ${ }^{1-4,16}$. There are several reports in the literature of patients with PDPH for more than six months, representing chronic headache that is successfully treated with blood patch ${ }^{1-3,16}$. After a literature search on the subject, and ruling out other causes of headache, we decided to treat the chronic headache of the patient presented here with a blood patch, which resulted in complete resolution of the headache. We contacted the patient by telephone three weeks after the treatment to verify the treatment efficacy suggested in literature.

Vascular changes can occur or be perpetuated with daily stress, and it can be one more factor for maintenance of PDPH ${ }^{2}$. The marked hypercortisolism seen in response to stress observed in some patients can interfere with the release of the adrenocorticotropic hormone (ACTH) and cancel its potential beneficial effects, which would help the resolution of PDPH 9,17. Adrenocorticotropic hormone can increase the production of CSF, as well as beta-endorphins, therefore reducing the pain 9,17 .

Blood patch with autologous blood is the most effective treatment for persistent PDPH ${ }^{5,18}$. Approximately 10 to $20 \mathrm{~mL}$ of autologous blood can be injected in the epidural space close to the intervertebral space in which the dura mater puncture occurred ${ }^{14}$. In a Brazilian study using $10 \mathrm{~mL}$ of autologous blood in the epidural space immediately above the space of prior puncture resulted in complete relief of symptoms in $98.3 \%$ of patients ${ }^{5}$. This therapeutic intervention allowed the discharge of patients in less than 24 hours ${ }^{5}$. The headache disappears when blood closes the orifice and causes the immediate closure of the fistula, observed in approximately $100 \%$ of the cases in which the blood patch was used ${ }^{12}$. Local compression increases the subarachnoid pressure, forcing the cephalad migration of CSF ${ }^{7}$. The most common side effects of blood patch include pain in the dorsal region and radicular pain; however, hematoma or abscess can also be seen ${ }^{1,12}$.

The greatest benefits of blood patch in PDPH include the possibility of diagnosis and treatment, and it has been recommended when other causes of headache have been ruled out ${ }^{1-4,16}$. In the case presented here, we decided to treat the patient performing a blood patch instead of the conservative treatment after observing reports in the literature of complete pain resolution in similar cases of chronic pain after spinal anesthesia 1,3,4,16,19, absence of central nervous system pathologies that justified the pain, and history of spinal anesthesia for a surgical procedure. Complications were not observed immediately or even three weeks after treatment.

The case presented here demonstrated that epidural blood patch is effective in treating chronic headache after dural puncture in a case with a seven-months duration. 


\section{REFERÊNCIAS / REFERENCES}

01. Klepstad P - Relief of postdural puncture headache by an epidural blood patch 12 months after dural puncture. Acta Anaesthesiol Scand, 1999;43:964-966.

02. MacArthur C, Lewis M, Knox EG - Accidental dural puncture in obstetric patients and long term symptoms. BMJ, 1993;306:883-885.

03. Ferre JP, Gentil ME - Seven months delay for epidural blood patch in post-dural puncture headache. Eur J Anesthesiol, 1999;16:257-258.

04. Turnbull DK, Shepherd DB - Post-dural puncture headache: pathogenesis, prevention and treatment. BMJ, 2003;91:718-729.

05. Pedrosa GC, Jardim JL, Palmeira MA - Tampão Sanguíneo Peridural e a Alta Hospitalar Precoce: Análise de 60 Pacientes Portadores de Cefaleia Pós-Raquianestesia. Rev Bras Anestesiol, 1996;46:8-12.

06. Evans RW, Armon C, Frohman EM et al. - Assessment: prevention of post-lumbar puncture headaches. Report of the therapeutics and technology assessment subcommittee of the American Academy of Neurology. Neurology, 2000;55:909-914.

07. Gaiser R - Postdural puncture headache. Curr Opin Anaesthesiol, 2006;19:249-253.

08. Vandam LD, Dripps RD - Long-term follow-up of patients who received 10098 spinal anesthetics. JAMA, 1954;156:1486-1491.

09. Barbosa FT, Cunha RM - É possível usar a hidrocortisona no tratamento da cefaleia após raquianestesia. Rev Bras Anestesiol, 2007:57:450-451.

10. Grant R, Condon B, Hart I et al. - Changes in intracranial CSF volume after lumbar puncture and their relationship to post-LP headache. J Neurol Neurosurg Psych, 1991;54:440-442.

11. Yentis SM, Haire K - Epidural blood patch for atypical headache following obstetrical epidural analgesia. Anaesthesia, 1997;52:62-64.

12. Cooper G - Epidural blood patch. Eur J Anaesthesiol, 1999;16:211215.

13. Cavicchio A, Imbelloni LE - Cefaleia Pós-Punção. em: Imbelloni LF Tratado de Anestesia Raquidiana. Curitiba, Posigraf, 2001;178-191.
14. Bernards CM - Epidural and spinal anesthesia. em: Barash PG, Cullen BF, Stoelting RK - Clinical Anesthesia. Nova York, Lippincott Williams \& Wilkins, 2006:691-617.

15. Flaatten $H$, Felthaus J, Kuwelker $M$ et al. - Postural post-dural puncture headache. A prospective randomised study and a meta-analysis comparing two different $0.40 \mathrm{~mm}$ O.D. (27g) spinal needles. Acta Anaesthesiol Scand, 2000;44:643-647.

16. Wilton NCT, Globerson H, Rosayro AM - Epidural blood patch for postdural puncture headache: its never too late. Anesthesia and Analgesia 1986;65:895-896.

17. Kshatri AM, Foster PA - Adrenocorticotropic hormone infusion as a novel treatment for postdural puncture headache. Reg Anesth, 1997;22:432-434.

18. Polpun B, Suhattaya B - Epidural blood patching for preventing and treating post-dural puncture headache. Cochrane Database of Systematic Reviews. Cochrane Library, (4):CD001791.

19. Davies JM, Murphy A, Smith M et al. - Subdural haematoma after dural puncture headache treated by epidural blood patch. $\mathrm{Br} J$ Anaesth 2001;86:720-723.

Resumen: Barbosa FT - Cefalea posterior a la Anestesia Subaracnoidea con Siete Meses de Evolución: Relato de Caso.

Justificativa y objetivos: La cefalea postpunción dural es una complicación posible y esperada en una pequeña parte de los casos posteriores a la realización de la raquianestesia. Este relato quiso describir la conducta terapéutica tomada frente a un caso de cefalea postpunción de dura madre con siete meses de evolución.

Relato del caso: Paciente del sexo femenino, 40 años, anteriormente sana, que se presentó en el hospital con un cuadro de cefalea con siete meses de duración y que se inició después de la realización de la raquianestesia. Al ser examinada, relató que algunos analgésicos y la posición de decúbito le aliviaban parcialmente el dolor. Después de sospechar de una cefalea postpunción dural, se realizó un tampón sanguíneo epidural, con la resolución completa del cuadro. Recibió alta sin quejarse.

Conclusiones: El presente caso demostró que el tampón sanguíneo epidural fue eficaz en el tratamiento de la cefalea crónica postpunción dural en un caso con siete meses de duración.

Descriptores: COMPLICACIONES, Cefalea, postpunción de la dura madre; SANGRE; TÉCNICAS ANESTÉSICAS, Regional: subaracnoidea. 